\title{
The Effect of Energy Consumption, Energy Resources, Economic Growth, and Road Infrastructure on $\mathrm{Co}_{2}$ Emissions in Indonesia
}

\author{
Zulfikar*, Sofyan Syahnur, M. Shabri Abd. Majid \\ Department of Economics, Faculty of Economics and Business, Universitas Syiah Kuala, Darussalam, Banda Aceh, Indonesia
}

*Corresponding author email: zulfikarjoel32@yahoo.com

\begin{abstract}
This study aims to analyze the effect of energy resources, energy consumption, and road infrastructure on economic growth and their effect on $\mathrm{CO}_{2}$ emissions in Indonesia. This study uses time series data in Indonesia for the period 2000 to 2019 and the analytical model used is the Auto Regressive Distributed Lag (ARDL) model. The results found in this study are variables that have a significant effect on economic growth in the short term are road infrastructure in the same period, in the previous period, as well as in the previous 2 periods and resources. Meanwhile, the ones that have a significant effect in the long term are road infrastructure and energy resources. Variables that have a significant effect on $\mathrm{CO}_{2}$ emissions in the short term are road infrastructure, energy consumption in the previous period, economic growth in the previous period, energy consumption and energy resources. While the variables that influence in the long term are economic growth and energy resources.
\end{abstract}

Keywords: Energy Consumption, Energy Resources, Economic Growth, Road Infrastructure and Co2 Emissions

\section{Introduction}

In the 18th century, the industrial revolution that occurred in England had a significant impact on industrial development in the world today. The development of this industry accelerates the pace of the world economy caused by the rapid pace of industrial processes that occur. However, according to Firmansyah dan Gunawan (2007) that success in the economy has an impact on the decline in environmental quality. One of them is caused by the increasing retention of carbon and other greenhouse gases over time. According to Suhardi and Purwanto (2015), Indonesia is the fourth largest emitter per capita in the world after China, America and the European Union. The sector that causes high levels of emissions in Indonesia according to the Secretary General of National Energy Council (2019) results from industries that use $70 \%$ of fossil energy from the total energy consumed.

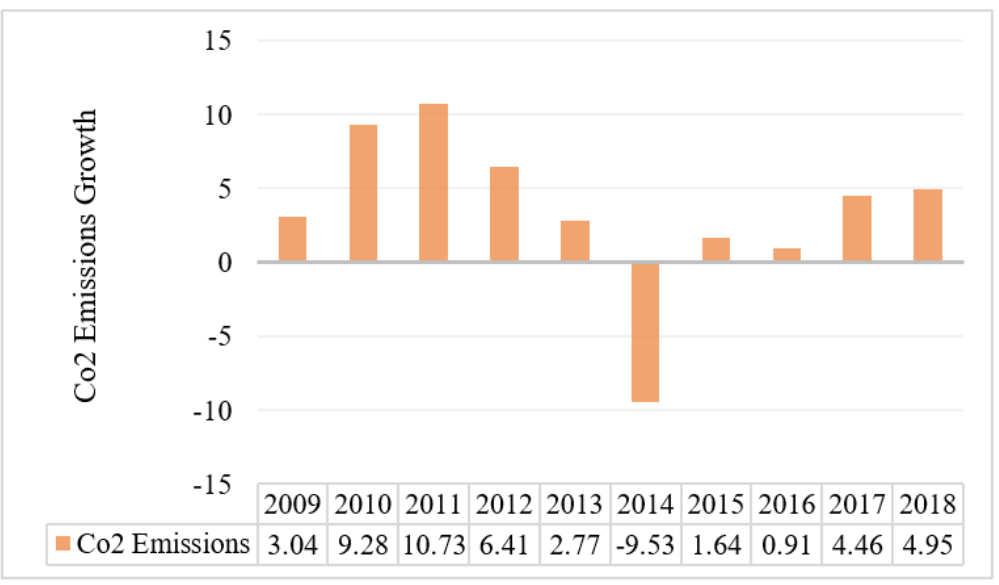

Figure 1. Growth of CO2 Emissions in Indonesia, 2009-2018

Source: Central Bureau of Statistic, (2020) 
The highest $\mathrm{CO}_{2}$ emissions as shown in Figure 1 occurred in 2011 due to Indonesia's economic growth in that year growing to $5.26 \%$ even though globally in that year the world's economic condition was slowing due to the European debt crisis. However, it is different with Indonesia which can show its ability to survive (Ministry of Energy and Mineral Resources, 2018).

Chen et al. (2020) said the high $\mathrm{CO}_{2}$ emissions were of course due to the high use or consumption of energy. Indonesia as in general other developing countries still use fossil fuels in their daily consumption, both the government and the private sector and the population. The private sector, such as industrial needs, results in high $\mathrm{CO}_{2}$ produced, for example to turn on large machines that use fuel oil and or use coal. These two things also show the use of non-renewable energy and have become a benchmark for the government, especially developing countries, to reduce dependence on non-renewable resources. This finding is in line with the results obtained by O'Ryan et al. (2020), Kang et al. (2019) and Jebli et al. (2020). Consumption of fuels such as energy oil, coal resources, and gas in Indonesia in the last eight years generally tends to increase. Figure 2 shows fluctuations in oil consumption that increased greatly in 2014 amounting to 80.7 million tons and decreased in 2015 to 73.8 million tons, in subsequent years the consumption increased until 2018 reaching 83.4 million tons. Fossil coal energy consumption also experienced the same fluctuation from 2008 at 31.5 million tons and until 2018 it reached 61.6 million tons.

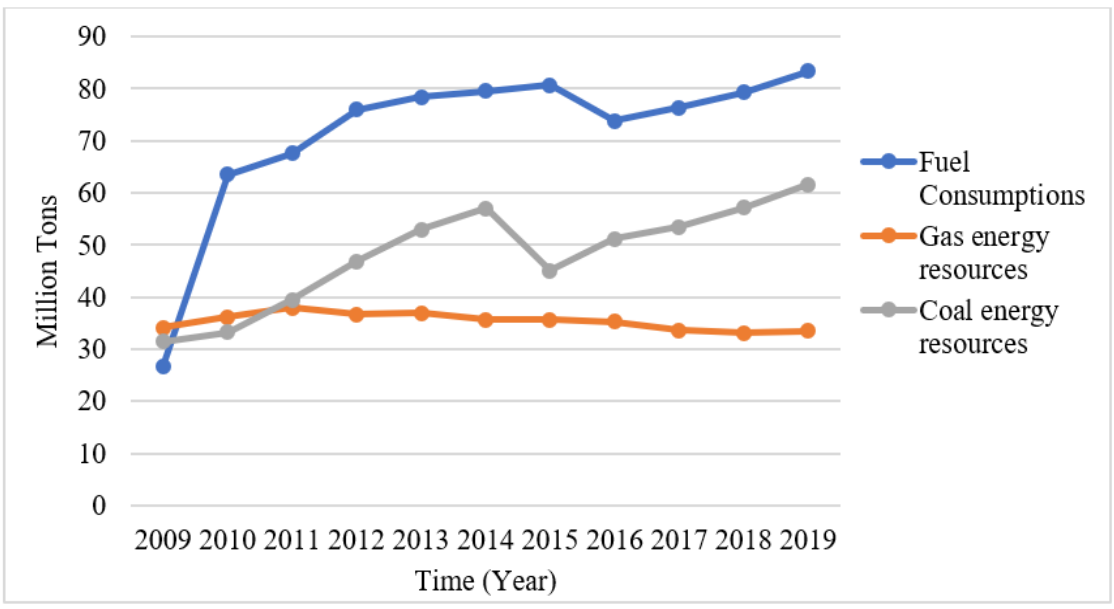

Figure 2. Growth in Energy Consumption of Fuel Oil, Coal Energy Resources, and Coal Gas Energy Resources 2010-2018 (Million Tons)

Source: Central Bureau of Statistic (2020)

Furthermore, the consumption of gas resources also experienced a fluctuating rate of increase in consumption patterns, in 2008 of 34.1 million tons and tended to continue to increase until 2014 by 35.7 million tons and again experienced a slight decline until 2018 of 33.5 million tons, which is the impact of the comprehensive implementation of the kerosene to LPG conversion program to areas that were previously untouched by government programs (Ministry of Energy and Mineral Resources, 2018). Energy consumption continues to increase along with the development of infrastructure growth, especially roads, which are ensured to facilitate the mobilization of goods and services (Zhang et al., 2016). Melese et al., (2017) and Tamura et al., (2018) said that the use of transportation services or means, both individually and within the scope of the company and various industrialization activities, will automatically have an impact on the amount of carbon dioxide emissions released by vehicles.

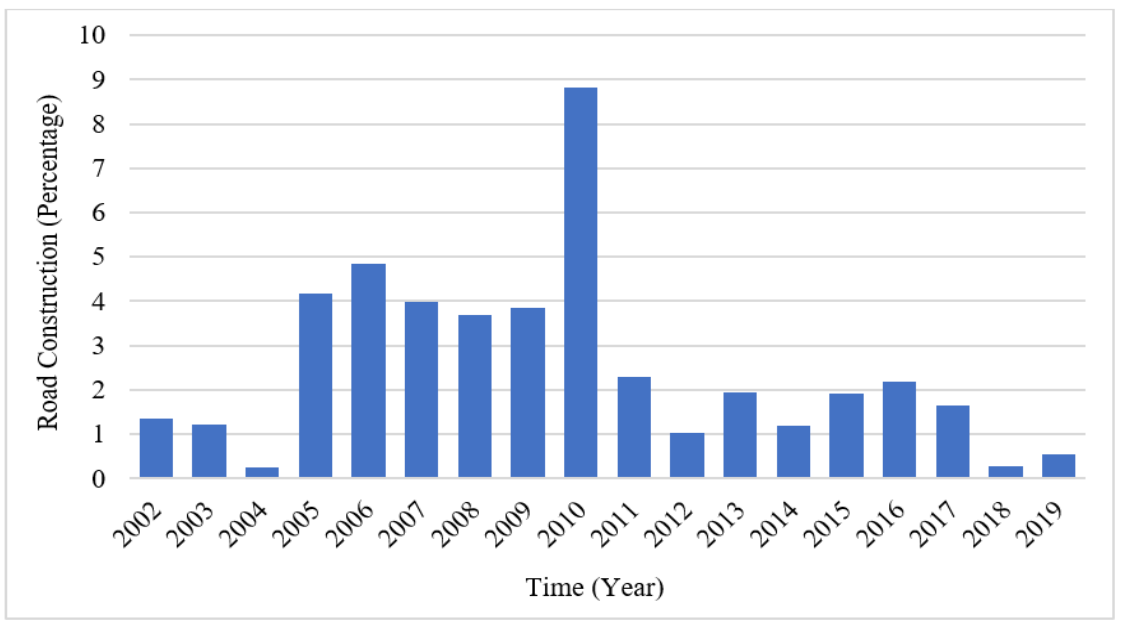

Figure 3. Growth of Road Construction in 2001-2018 (Percent) Source: Central Bureau of Statistic (2020) 
Figure 3 shows the projected growth of roads during 2001-2018. Road infrastructure development experienced a very high growth in 2009 from $3.85 \%$ in 2008 to $8.81 \%$ in 2009. This shows that the projected infrastructure development continues to be optimized by the government. But in the following year it experienced a sharp slowdown until it reached $0.55 \%$ in 2018 . Along with the development of economic globalization in a country, every year it continues to increase along with the demands of the times that make every country, both developed and developing countries, continue to improve themselves. Economic growth basically affects every other macroeconomic variable policy, in this case that the high economic growth, especially Indonesia as a developing country, but its fluctuations always show a significant growth projection.

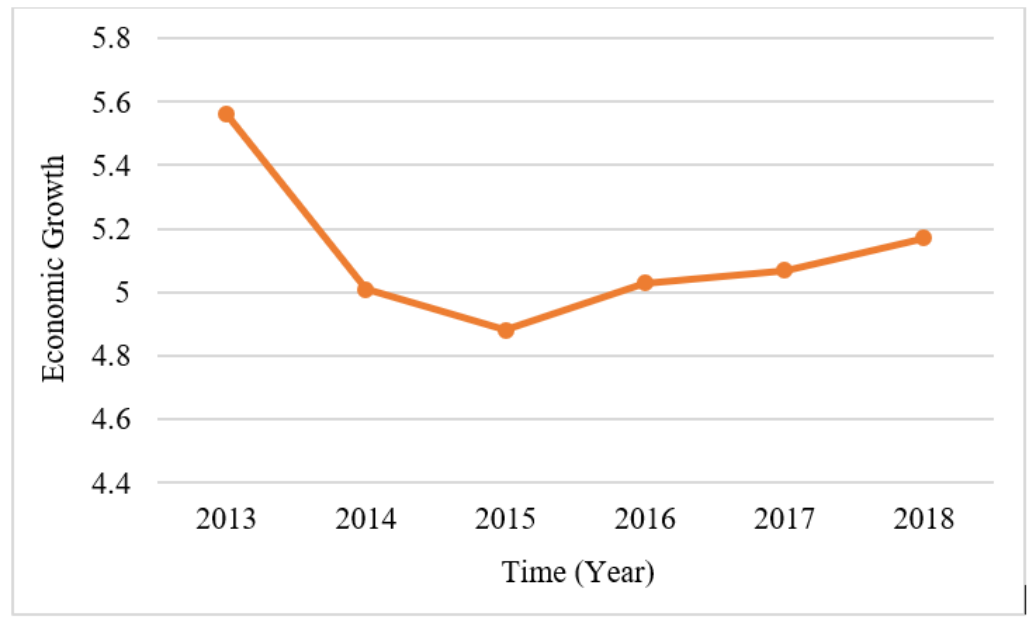

Figure 4. Indonesia's Economic Growth in 2013-2018 (Percent

Source: Bank Central of Indonesia (2021)

Figure 4 depicts Indonesia's economic growth from 2013 to 2018 which continues to experience growth. The highest growth occurred in 2013 which amounted to $5.56 \%$ and then experienced a slowdown until 2015 to $4.88 \%$. In 2015 to 2018 it continued to increase to reach $5.17 \%$ in 2018. This shows an improvement in various sectors, both in terms of capital and various macroeconomic factors as a whole and a strong level of anticipation in terms of reducing the impact of global economic shocks. Orecchini et al. (2018) said that along with the growing rate of economic growth, the amount of carbon dioxide emissions continued to fluctuate and increase. Various studies have been carried out to reduce emission growth rates and various other developed countries have made various efforts to use renewable energy in order to have a positive impact on reducing $\mathrm{CO}_{2}$ emissions and have a direct impact on the surrounding environment for the long term, as well as reducing exhaust emissions from various transportation vehicles. used by the general population. This is in line with the findings produced by the research of Wang et al. (2019) and Ehigiamusoe et al. (2020).

Basically, as a country develops, consumption in various sectors also shows a large increase, considering that the contribution generated will also be even greater. High consumption causes high energy resources used in carrying out various activities, both by the government sector and the private sector. The use of energy resources in Indonesia in 2014 decreased significantly by $12.74 \%$ from 92.6 million tons to 80.8 million tons. This is in line with the decrease in $\mathrm{CO}_{2}$ emission rate in 2014 by $9.53 \%$. The resulting impact is a slowdown in Indonesia's economic growth from $5.26 \%$ in 2013 to $4.77 \%$ in 2014 . The energy is one of the important factors determining economic growth. over the past few years, this has led to a high spike in carbon dioxide emissions, where after 2014 the emission rate tends to continue to increase to $4.95 \%$ in 2018 . This of course has the impact of decreasing the quality of the environment in Indonesia (Wang et al., 2016).

Helda et al. (2018) in his research aims to see the impact generated by economic growth from the industrial and transportation sectors on increasing pollution in Indonesia. The results of his research found that there is a relationship both short and long term to the increase in pollution. However, this study only focuses on the rate of GDP for each sector, so it has not been able to capture the detailed phenomenon of infrastructure. Due to the limitations of this study, this study focuses more on infrastructure indicators on the length of roads built in Indonesia because in recent years economic development in Indonesia has focused more on infrastructure development so that between regions can be connected. Based on the previous discussion, it is interesting to study the effect of energy consumption variables, and the use of energy resources, economic growth, and road infrastructure on carbon dioxide emissions in Indonesia. Therefore, this research is very important considering that energy consumption in Indonesia is increasingly showing an increase both due to economic growth and other factors such as increased use of vehicles, the manufacturing industry, causing higher energy consumption which has a direct impact on high carbon dioxide emissions. 


\section{Literature Review}

Water and air pollution or commonly called pollution is the entry or inclusion of components such as living things, energy, or substances into the water/air so that it has an impact on changing the composition of the water/air either due to human activities or natural processes so that the quality of the water/air decreases to certain level so that it becomes less or cannot be used again as it was originally intended (Kuncoro et al., 2020; Listyarini et al., 2021). Some of the factors that cause increased pollution are the growing industrial sector as a result of the disposal of waste from the industry, both water waste and air waste. Greenstone and Fan (2019) says that the current level of pollution in Indonesia makes the average Indonesian lose 1.2 years of life expectancy. In this condition, the improvement of the economy should pay more attention to the resulting effect on pollution.

What is even more worrying is that until now Indonesia does not have a national standard related to air pollution control, while the Indonesian economy continues to grow positively so that the chances of damage or pollution to the air are higher. One of the pollutions that occur in Indonesia is the emission of carbon dioxide $\left(\mathrm{CO}_{2}\right)$ from exhaust gases which are very dangerous for the environment, including humans. The amount of gas is not small in urban areas because the fewer green open areas are inversely proportional to the increasing number of vehicles and factories operating.

$\mathrm{CO}_{2}$ emissions are affected by many things. Suhardi and Purwanto (2015) said that one of the biggest factors causing increased $\mathrm{CO}_{2}$ emissions is the number and type of industry. This finding is certainly very relevant to the conditions in Indonesia where industrialization is happening to the economy in Indonesia.

The development of global market mechanisms and the use of more advanced technology triggers the high use of energy in various sectors which has a negative effect on environmental pollution. Especially the use of energy in various industries, both the manufacturing industry and the agricultural industry. Given that the agricultural industry is one of the most important industries in every country, especially developed countries with such a large use of energy, both in terms of population and per capita consumption (Zhang et al., 2020). Proper management of energy consumption will provide support or a large effect on the sustainability of development in a country (Shang et al., 2019).

The use of renewable energy is the main policy being carried out by various developed countries in the world. It is possible that the use of non-renewable energy will have a negative effect on the environment in the long term. The use of energy sourced from fossils such as only oil, gas, and coal will certainly provide opportunities for environmental damage that will result in mass damage such as natural disasters (Fabre et al., 2019).

As the study conducted by Viviescas et al. (2019) in Latin America, shows that the use of renewable energy such as the use of hydro, solar and wind energy has a positive impact both in the long and short term. The results of the study in the Brazilian region show that the use of wind power is more dominant than the use of energy resources from solar power. This study is similar to that conducted by Wang et al. (2019) in Pakistan shows the opportunity to use renewable energy such as hydro, solar and wind power plants to reduce the high cost of government spending. These are the same results for the use of renewable energy in Korea (Yeom et al., 2020).

The development of infrastructure must certainly be the government's top priority in suppressing the level of carbon dioxide reduction as studied by $\mathrm{Li}$ et al. (2020) in China where each development or use of resources is positively related to high $\mathrm{CO}_{2}$. The positive role between road infrastructure and the mobilization of transportation such as roads, railways, ports and airports has become a strategic discussion, especially for developed countries that are members of the OECD and ASEAN, which until now remember the increasing needs of globalization. In addition, other evidence that proves the need for road infrastructure, especially transportation, is carried out by Park and Seo (2016) and Jaffee (2015).

\section{Materials and Methods}

\subsection{Materials}

The use of the data used in this study is secondary data and the data were obtained from various reputable sources, including BP Statistical and the Central Bureau of Statistics as well as several other study sources deemed relevant to support this study. The data used is in the form of an annual time series, namely time series data from 2000 to 2019. The model used in this study is the ARDL model. The ARDL model is used to estimate the linear regression model in analyzing long-term relationships based on the cointegration relationship between variables with time series data types. The advantage of using the ARDL model is that it can produce estimation results that are consistent in the long term.

\subsection{Methods}

The ARDL model is also able to answer theories that are static to dynamic because they can calculate based on the known length of the lag difference. This model can also distinguish the long-term response and short-term response of the dependent variable to changes in the value of the independent variable. The research model proposed in this study is as follows: 


$$
P E_{t}=\beta_{0}+\varphi_{1} K E_{t}+\ldots+\varphi_{q} K E_{t-q}+\varphi_{1} S E_{t}+\ldots+\varphi_{q} S E_{t-q}+\varphi_{1} I N F_{t}+\ldots+\varphi_{q} I N F_{t-q}
$$

Furthermore, the second research model is to answer the hypothesis whether the variables of economic growth, energy consumption, energy resources, and infrastructure have a positive effect on $\mathrm{CO}_{2}$ emissions both in the long and short term:

$$
\begin{gathered}
E K_{t}=\beta_{0}+\varphi_{1} P E_{t}+\cdots .+\varphi_{q} P E_{t-q}+\varphi_{1} K E_{t}+\cdots .+\varphi_{q} K E_{t-q}+\varphi_{1} S E_{t}+\cdots \\
+\varphi_{q} S E_{t-q}+\varphi_{1} I N F_{t}+\ldots+\varphi_{q} I N F_{t-q}
\end{gathered}
$$

Where:

EK: $\mathrm{CO}_{2}$ Emission

PE: Economic Growth

TO: Energy Consumption

SE: Energy Resources

INF: Road Infrastructure

\section{Results and Discussion}

Before conducting an analysis of the ARDL model, it is necessary to carry out several examinations of the data used through the stationarity test and cointegration test. Stationarity test is an initial requirement in order to be able to analyze through the ARDL model. Many tests have been developed to be able to test this stationarity including Levin, Lin, and Chu (LLC), Augmented Dickey Fuller, and so on. The purpose of the stationarity test is to see if there is a unit root of each variable being tested. Meanwhile, each variable was tested at the stationary level at the level, but if there are variables that are not stationary, it will be continued at the stationary level in the first difference. Of all the variables tested, there is at least one variable that is stationary in the first difference. The variables tested in this stationary test are the variables of economic growth, carbon emissions, energy resources, energy consumption, and road infrastructure.

The stationarity test used in this study is the Augmented Dickey-Fuller (ADF) test. The results of the stationarity test at the level show that only energy resources have been stationary at the level so that it is continued with the stationarity test at the first difference. Based on the ADF test in the first difference, it shows that all variables are stationary. Furthermore, the cointegration test was carried out where it was found that the variables used were cointegrated or had long-term balance. This shows that the ARDL model that is formed can be continued at the

\begin{tabular}{|c|c|c|c|c|}
\hline $\begin{array}{l}\text { Variable } \\
\text { (1) }\end{array}$ & $\begin{array}{l}\text { Coefficient } \\
\text { (2) }\end{array}$ & $\begin{array}{l}\text { Std. Error } \\
\text { (3) }\end{array}$ & $\begin{array}{l}\text { t-Statistic } \\
(4)\end{array}$ & $\begin{array}{c}\text { Prob. } \\
(5)\end{array}$ \\
\hline \multicolumn{5}{|c|}{ Short Run } \\
\hline $\mathrm{PE}(-1)$ & 0.250991 & 0.236005 & 1.063501 & 0.3103 \\
\hline INF & -0.000041 & 0.000012 & -3.366605 & 0.0063 \\
\hline $\mathrm{INF}(-1)$ & 0.000064 & 0.000022 & 2.889334 & 0.0147 \\
\hline $\operatorname{INF}(-2)$ & -0.000041 & 0.000012 & -3.491023 & 0.0050 \\
\hline $\mathrm{KE}$ & -0.012525 & 0.033623 & -0.372508 & 0.7166 \\
\hline SE & 0.063513 & 0.032189 & 1.973171 & 0.0741 \\
\hline $\mathrm{C}$ & 8.926463 & 3.197855 & 2.791391 & 0.0175 \\
\hline \multicolumn{5}{|c|}{ Long Run } \\
\hline INF & -0.000025 & 0.000009 & -2.810036 & 0.0170 \\
\hline $\mathrm{KE}$ & -0.016722 & 0.046249 & -0.361565 & 0.7245 \\
\hline SE & 0.084797 & 0.033396 & 2.539143 & 0.0275 \\
\hline $\mathrm{C}$ & 11.91770 & 2.163406 & 5.508770 & 0.0002 \\
\hline \multirow{2}{*}{\multicolumn{2}{|c|}{$\begin{array}{c}\text { R-squared } \\
\text { Adjusted R-squared }\end{array}$}} & 0.790214 & F-statistic & 6.905747 \\
\hline & & 0.675786 & Prob (F-statistic) & 0.003072 \\
\hline
\end{tabular}
analysis stage (See Table 1).

Table 1. Estimation Results of Short-Term and Long-Term ARDL Models on Economic Growth

The coefficient of determination shows that the independent variable is able to explain the variation in the value of the dependent variable by $79.02 \%$. This indicates that the model formed, and the variables used are appropriate to explain the variables of economic growth. The $\mathrm{F}$ test is used to see whether the independent variables have a significant effect or not simultaneously on the dependent variable. From the Prob (F-statistic) value which is smaller 
than the alpha value (0.1), it can be concluded that the independent variables jointly affect economic growth in Indonesia.

Referring to the results of the study in Table 1, the road infrastructure variable was found to have a negative and significant effect on carbon emissions where every 1-kilometer increase in roads will reduce economic growth by $0.000041 \%$ in the short term. This is contrary to theory but acceptable if it has a negative effect in the short term because the impact resulting from road infrastructure development has an impact on the long term. This is supported by the findings on road infrastructure in the previous period that had a significant effect and had a positive direction where every increase in road infrastructure in the previous period of 1 kilometer was able to increase economic growth by $0.000064 \%$. Meanwhile, road infrastructure in the previous 2 periods again had a negative and significant impact on economic growth where every $1 \mathrm{~km}$ increase of roads in the previous 2 periods would reduce economic growth by $0.000041 \%$. This is contrary to the theory which states that any improvement in road infrastructure has a positive effect on economic growth. This effect is caused by the number of roads being refurbished, while land clearing is needed for the construction of significant new roads so that between regions become connected and more effective in carrying out economic activities.

The energy resource variable has a positive effect on economic growth, which means that every increase of 1 million tons of energy resources will increase economic growth by $0.006 \%$. This is because the energy resources owned by Indonesia, whether used or exported abroad, are able to increase production activities and increase the country's foreign exchange so that the country's ability to carry out activities or programs that increase economic growth is also greater.

However, there is a variable that does not significantly affect economic growth statistically in the short term, namely the energy consumption variable. This is because even though the industrialized economy has begun to have a significant effect, it cannot be denied that the agricultural sector still contributes a very large share to economic growth. Meanwhile, the majority of agriculture in Indonesia still uses traditional methods so that technology has not played a significant role in the development of the agricultural sector. This is the reason why the use of energy consumption is still not optimal for economic growth in Indonesia (Reflis et al., 2011).

After the short-term interpretation, the long-term interpretation is carried out. The ARDL model in the long term shows that there is a statistically significant effect of road infrastructure and energy resources variables on economic growth that occurs. The influence given by road infrastructure still tends to be very small on economic growth and has a negative effect. This can happen because there are some infrastructure developments that are not yet effective and on target as well as the construction of several infrastructures that spend a large budget but the resulting impact is still very small, such as the construction of the Trans Papua Road in Papua Province which spends a lot of budgets but cannot be enjoyed by all Papuan people to the fullest.

The next factor that has a significant effect on economic growth is energy resources and the effect given is positive, which means that every increase in energy resources in Indonesia by 1 million tons will increase economic growth by $0.085 \%$. This is due to the wheels of the economy provided by the industrial world as well as several factors of population mobility that indirectly affect the economic activities that occur. Furthermore, the energy consumption variable has not been able to provide a significant effect in the long term. This is due to the uneven use of energy consumption between regions so that there are still areas that have not been able to maximize the consumption of available energy for a more optimal production process so that later it is expected to be able to increase economic growth in Indonesia (Hiron et al., 2021).

These results indicate that the road infrastructure development that has been carried out has not been able to have a major impact on the Indonesian economy. This is because the study of its function or influence on the process of economic activity is not yet precise, so that the impact given by road infrastructure on the economy has not been maximized in the short and long term. However, if viewed from the energy resources owned by Indonesia, it is able to have a positive and significant impact on Indonesia's economic growth both in the short and long term. This finding is inseparable from the high wealth of energy resources owned by Indonesia where Indonesia has coal, oil, gas, and so on. But the energy resources that are so rich in Indonesia cannot necessarily be used optimally where energy consumption in Indonesia has not had a significant effect on economic growth.

The model that has been interpreted has met the best lag selection and the CUSUM test. The test for selecting the best lag resulted in the ARDL model $(1,2,0,0)$ as the best model based on the Akaike Information Criteria for the 20 best models (attachment). Furthermore, the CUSUM test is used to see the balance of the model that occurs with a confidence level of 95\%. The results of the CUSUM test for the ARDL model $(1,2,0,0)$ indicate that the model is stable. The next model analyzed in this study is the effect of economic growth, road infrastructure, energy resources, and energy consumption on $\mathrm{CO}_{2}$ emissions in Indonesia. Based on the cointegration test, it shows that there is a longterm equilibrium of the former model. After passing the cointegration test, the next step is to analyze the short-term ARDL model. The results of the ARDL model can be seen in Table 2.

Based on the Table 2, it shows that the factors used in this study can explain $\mathrm{CO}_{2}$ emissions up to $99.02 \%$. Meanwhile, based on the resulting $\mathrm{F}$ test, it shows that together they can affect $\mathrm{CO}_{2}$ emissions in Indonesia. The variables that affect $\mathrm{CO}_{2}$ emissions in Indonesia in the short term are infrastructure, energy consumption, energy consumption in the previous period, economic growth in the previous period and energy resources. 
Table 2. Estimation Results of Short-Term and Long-Term ARDL Models on $\mathrm{CO}_{2}$ Emissions

\begin{tabular}{ccccc}
\hline $\begin{array}{c}\text { Variable } \\
(1)\end{array}$ & $\begin{array}{c}\text { Coefficient } \\
(2)\end{array}$ & $\begin{array}{c}\text { Std. Error } \\
(3)\end{array}$ & $\begin{array}{c}\text { t-Statistic } \\
(4)\end{array}$ & $\begin{array}{c}\text { Prob. } \\
(5)\end{array}$ \\
\hline EK(-1) & & Short Run & \\
EK(-2) & -0.253744 & 0.398198 & -0.637232 & 0.5442 \\
INF & 0.584862 & 0.364641 & 1.603941 & 0.1528 \\
INF(-1) & -0.002090 & 0.000804 & -2.599156 & 0.0355 \\
INF(-2) & -0.001017 & 0.001353 & -0.751541 & 0.4768 \\
KE & 0.001537 & 0.000896 & 1.715110 & 0.1300 \\
KE(-1) & 6.119303 & 2.572265 & 2.378955 & 0.0490 \\
PE & -3.934453 & 1.979261 & -1.987840 & 0.0872 \\
PE(-1) & -3.632958 & 13.69557 & -0.265265 & 0.7984 \\
SE & -33.87691 & 11.27728 & -3.003997 & 0.0198 \\
C & 6.161889 & 1.666951 & 3.696503 & 0.0077 \\
Long Run & 679.6283 & 193.5325 & 3.511701 & 0.0098 \\
\hline INF & & & & 0.1004 \\
KE & -0.002346 & 0.001240 & -1.892154 & 0.3074 \\
PE & 3.266418 & 2.967194 & 1.100844 & 0.0802 \\
SE & -56.07840 & 27.42764 & -2.044594 & 0.0720 \\
C & 9.212213 & 4.351025 & 2.117251 & 0.0474 \\
R-squared & 1016.065 & 423.2737 & 2.400492 & 70.45358 \\
Adjusted R-squared & & 0.990162 & F-statistic & 0.000005 \\
\hline
\end{tabular}

Referring to Table $2, \mathrm{CO}_{2}$ emissions in the previous period and the previous 2 periods have no significant effect on $\mathrm{CO}_{2}$ emissions in the current period. This occurs due to fluctuations in the resulting $\mathrm{CO}_{2}$ emissions where in addition to the impact of economic activities and so on that can increase $\mathrm{CO}_{2}$ emissions, there are activities to protect protected forests and use renewable energy resources. This is in accordance with research conducted by Alviya et al., (2018) which states that $\mathrm{CO}_{2}$ emissions can be reduced and reduced through protected forests and community involvement in protecting the environment.

Furthermore, the road infrastructure variable has a negative and significant effect in the short term on $\mathrm{CO}_{2}$ emissions. Every $1 \mathrm{~km}$ increase in road infrastructure will reduce $\mathrm{CO}_{2}$ emissions by $0.003 \%$, which is still relatively small. This finding is supported by infrastructure in the previous period as well as the previous 2 periods which did not significantly affect $\mathrm{CO}_{2}$ emissions in Indonesia. This of course can happen because the impact of increasing population mobility using transportation modes for both economic and social activities occur in the long term. The energy consumption variable also has a significant positive effect in the short term on the $\mathrm{CO}_{2}$ emission variable where every 1 million ton increase in energy consumption can increase $\mathrm{CO}_{2}$ emissions by $6.119 \%$. This is inseparable from the impact of using energy that is not environmentally friendly, thus creating harmful $\mathrm{CO}_{2}$ emissions on air quality. However, the $\mathrm{CO}_{2}$ emissions formed in the current period can be suppressed by programs or supervision carried out by the government to be able to absorb $\mathrm{CO}_{2}$ emissions from the previous period and tend to be successful in the current period. This is indicated by the coefficient of energy consumption in the previous period is negative and has a significant effect.

Furthermore, there is an energy resource variable where this factor has a positive and significant effect on $\mathrm{CO}_{2}$ emissions in Indonesia in the short-term model. Each increase in energy resources in the same period by 1 million tons will increase $\mathrm{CO}_{2}$ emissions by $6.162 \%$. This is in accordance with research conducted by Elinur et al. (2010) where the energy resources owned increase industrial processes and production so as to increase $\mathrm{CO}_{2}$ emissions in the air.

The variable economic growth has no significant effect on the same period but has a negative and significant effect on the previous period on $\mathrm{CO}_{2}$ emissions. Every $1 \%$ increase in economic growth in the previous period can reduce 
$33.877 \%$. This shows that Indonesia is still showing determination to realize a green economy, which means that economic growth that occurs while maintaining the quality of the existing environment by controlling $\mathrm{CO}_{2}$ emissions so that the quality of the environment in Indonesia is still good.

After analyzing the short-term ARDL model, the next step is to continue the analysis of the long-term ARDL model. Based on the results of the long-term ARDL model, it shows that the variables of economic growth and energy resources have a significant effect on $\mathrm{CO}_{2}$ emissions in the long term. Meanwhile, road infrastructure and energy consumption variables have no significant effect on $\mathrm{CO}_{2}$ emissions in Indonesia in the long term.

Road infrastructure has a negative but not statistically significant effect on $\mathrm{CO}_{2}$ emissions in Indonesia. This is inseparable from the lack of precise function of the infrastructure built. In addition, because the existing infrastructure is only carried out maintenance of road infrastructure so that the distribution of transportation does not increase.

Furthermore, the energy consumption variable has a positive but not statistically significant effect on $\mathrm{CO}_{2}$ emissions in Indonesia. This finding is in accordance with the theory, but the effect of energy consumption has not significantly increased $\mathrm{CO}_{2}$ emissions. This is in accordance with research conducted by which the increase in energy consumption can be accompanied by slowing the increase in $\mathrm{CO}_{2}$ emissions so that the effect produced by energy consumption in the long term does not have a significant effect.

The next factor is energy resources that have a positive and significant long-term impact on $\mathrm{CO}_{2}$ emissions in Indonesia. Every 1 ton increase in energy resources will increase $\mathrm{CO}_{2}$ emissions by $9.212 \%$. This finding is in accordance with research conducted by Mulyana and Wirahadikusumah (2017) where the energy resources owned by Indonesia are also a resource for improving industrial and production processes so that it will increase $\mathrm{CO}_{2}$ emissions in Indonesia.

The last factor that has a significant negative effect on $\mathrm{CO}_{2}$ emissions is economic growth. This is inseparable from the program to realize a green economy that is continuously carried out so that the formed economy does not damage the environment without hampering the increase in economic growth. This finding is certainly an additional motivation in order to increase economic growth without having to sacrifice the environment as a result of this growth.

The results of the ARDL model have met the criteria for the best lag, which is at ARDL $(2,2,1,1,0)$. This is based on testing using the same Akaike Information Criteria method as in the previous ARDL model. Furthermore, the CUSUM test was carried out where with a confidence level of 95\% stating that the data model formed was stable.

Road infrastructure and energy consumption have not significantly affected $\mathrm{CO}_{2}$ emissions, so they are expected to be able to be controlled by various policies persuasively to raise awareness from all parties that the economy does not have to sacrifice environmental quality. In addition, the energy resources owned by Indonesia can be utilized optimally for both domestic and imported needs. This is so that future generations of residents can experience the same or even better quality than the current quality. Appropriate road infrastructure, appropriate and environmentally friendly energy consumption, and optimal management of energy resources will be able to increase quality economic growth without sacrificing environmental quality in both the short and long term.

\section{Conclussion}

The road infrastructure variable in the same period as well as in the previous 2 periods has a negative and significant effect in the short term on economic growth in Indonesia. Road infrastructure variables in the previous period and energy resources have a positive and significant impact in the short term on economic growth in Indonesia. Meanwhile, the variables of economic growth in the previous period and energy consumption in the same period did not have a statistically significant effect in the short term on economic growth in Indonesia. In the ARDL model for the long term, the road infrastructure variable has a negative and significant effect on economic growth in Indonesia. The energy resource variable also has a significant but positive coefficient on economic growth in Indonesia. Meanwhile, the energy consumption variable does not have a significant effect on economic growth in Indonesia.

The variables of road infrastructure, energy consumption in the previous period, and economic growth in the previous period have a negative and significant effect in the short term on $\mathrm{CO}_{2}$ emissions in Indonesia. Variables of energy consumption and energy resources in the same period have a positive and significant effect in the short term on $\mathrm{CO}_{2}$ emissions in Indonesia. Meanwhile, the $\mathrm{CO}_{2}$ emission variables in the previous period and the previous 2 periods, road infrastructure in the previous period and the previous 2 periods, and economic growth in the same period did not have a statistically significant effect in the short term on $\mathrm{CO}_{2}$ emissions in Indonesia. In the long-term ARDL model, the variable of economic growth in the same period has a negative and significant effect on $\mathrm{CO}_{2}$ emissions in Indonesia. Meanwhile, the energy resource variable has a positive and significant impact on economic growth in Indonesia. The variables of energy consumption and road infrastructure have not had a statistically significant effect on $\mathrm{CO}_{2}$ emissions in Indonesia. The two ARDL models formed show that they have met the cointegration test, which means that both models have a long-term equilibrium that occurs. In addition, both models have passed the CUSUM test, which means that both models are stable with a confidence level of $95 \%$.

Based on the conclusions that have been described previously, the suggestions that can be given in this study are as follows:

1. To be able to control the quality of the environment formed in Indonesia, it can be done by paying attention to variables that significantly affect $\mathrm{CO}_{2}$ emissions such as: 
a. Paying attention to the development of road infrastructure by conducting research related to economic benefits by considering the level of $\mathrm{CO}_{2}$ emissions that will increase. This is intended so that road infrastructure development needs to be built to connect several areas so that mobility and economic activities are easier to carry out and are within tolerable emission limits. This is done because infrastructure has a negative influence on economic growth in the long term so that the government is expected to be able to adjust priorities for road development in order to achieve economic growth that is in line with road infrastructure development, both in the short and long term.

b. Control energy consumption that is not environmentally friendly and replace it with environmentally friendly energy consumption so that $\mathrm{CO}_{2}$ emissions can be suppressed in order to create a green economy in Indonesia. This is certainly important to do so that every economic growth that is created, it can be ensured that the environment is maintained for the sustainability of the population afterwards.

c. Maximizing the energy resources in Indonesia. This is important because energy resources are one of the factors that support economic growth in Indonesia. Energy resources are used to drive many industries in Indonesia so that when energy resources can be maximized, the production process also produces maximum results. It is hoped that there will be a significant increase in economic growth in Indonesia.

d. Controlling $\mathrm{CO}_{2}$ emissions that are formed as a result of economic activities that occur so that quality economic growth will be created and does not have a significant impact on environmental quality degradation that occurs. $\mathrm{CO}_{2}$ emissions are certainly an unavoidable impact when energy is used, but $\mathrm{CO}_{2}$ levels can be controlled so that they do not exceed the tolerable levels. This is shown by the effect given by the results of the study where every decrease in $\mathrm{CO}_{2}$ levels is able to increase economic growth both in the short term and in the long term.

2. The process of increasing economic growth and controlling the quality of the environment is expected to be an evaluation material for the Government of Indonesia in order to improve and optimize programs to accelerate economic growth so that there will be a faster formation of welfare among communities that is more equitable but still pays attention to environmental quality because good environmental quality is a initial capital of great value to the sustainability of life in the future.

In connection with further research, it can be carried out using a longer time span and using panel data in order to be able to capture the impact of a more efficient and targeted economic growth improvement program without having to sacrifice environmental quality and be able to show the impact of each region on economic growth and $\mathrm{CO}_{2}$ emissions. formed. In addition, further research is also carried out to be able to see whether the green economy that occurs can be felt by every resident so that the level of welfare is more evenly distributed or only enjoyed by a portion of the population. Further research is also expected to be able to provide an explanation and elaboration of economic growth and $\mathrm{CO}_{2}$ emissions through other variables that are more specific to regional characteristics such as culture, etc.

\section{References}

Chen, X., Shuai, C., Zhang, Y., \& Wu, Y. (2020). Decomposition of energy consumption and its decoupling with economic growth in the global agricultural industry. Environmental Impact Assessment Review, 81, 106364.

Ehigiamusoe, K. U., Lean, H. H., \& Smyth, R. (2020). The Moderating Role of Energy Consumption in the Carbon EmissionsIncome Nexus in Middle-Income Countries. Applied Energy, 261, 114215.

Elinur, Priyarsono, D. ., Tambunan, M., \& Firdaus, M. (2010). Perkembangan Konsumsi dan Penyediaan Energi Dalam Perekonomian Indonesia. Indonesian Journal of Agricultural Economics (IJAE), 2(1), 97-119.

Fabre, A., Fodha, M., \& Ricci, F. (2020). Mineral resources for renewable energy: Optimal timing of energy production. Resource and Energy Economics, 59, 101131.

Firmansyah, M., \& Gunawan, D. S. (2007). Antara Pembangunan Ekonomi Dan Degradasi Lingkungan. Eko- Regional, 2(2), $105-112$.

Greenstone, M., \& Fan, Q. (2019). Indonesia's worsening air quality and its impact on life expectancy. Air Quality Life Index, 110.

Helda, N. P., Jamal, A., \& Dawood, T. C. (2018). Pengaruh Urbanisasi, Pertumbuhan PDB Sektor Industri dan Pertumbuhan PDB Sektor Transportasi Terhadap Polusi Lingkungan di Indonesia. Jurnal Ekonomi dan Kebijakan Publik Indonesia, 5(2), 168183.

Hiron, N., Busaeri, N., Sutisna, S., Nurmela, N., \& Sambas, A. (2021). Design of Hybrid (PV-Diesel) System for Tourist Island in Karimunjawa Indonesia. Energies, 14(24), 8311. 
Jaffee, D. (2015). A Deeper Channel Floats All Boats: The Port Economy as Urban Growth Engine. Environment and Planning A, 47(4), 783-800.

Jebli, M. Ben, Farhani, S., \& Guesmi, K. (2020). Renewable Energy, $\mathrm{CO}_{2}$ Emissions and Value Added: Empirical Evidence from Countries with Different Income Levels. Structural Change and Economic Dynamics, 53, 402-410.

Kang, S. H., Islam, F., \& Tiwari, A. K. (2019). The Dynamic Relationships Among $\mathrm{CO}_{2}$ Emissions, Renewable and NonRenewable Energy Sources, and Economic Growth in India: Evidence from Time-Varying Bayesian VAR Model. Structural Change and Economic Dynamics, 50, 90-101.

Kuncoro, A. H., Mellyanawaty, M., Sambas, A., Maulana, D. S., \& Mamat, M. (2020). Air Quality Monitoring System in the City of Tasikmalaya based on the Internet of Things (IoT). Jour of Adv Research in Dynamical \& Control Systems, 12(2), 24732479 .

Li, D., Wang, Y., Liu, Y., Sun, S., \& Gao, Y. (2020). Estimating life-cycle CO2 emissions of urban road corridor construction: A case study in Xi'an, China. Journal of Cleaner Production, 255, 120033.

Listyarini, S., Warlina, L., \& Sambas, A. (2021, March). Air Quality Monitoring System in South Tangerang Based on Arduino Uno: From Analysis to Implementation. In IOP Conference Series: Materials Science and Engineering (Vol. 1115, No. 1, p. 012046). IOP Publishing.

Melese, Y., Heijnen, P., Stikkelman, R., \& Herder, P. (2017). An Approach for Flexible Design of Infrastructure Networks Via a Risk Sharing Contract: The Case of $\mathrm{CO}_{2}$ Transport Infrastructure. International Journal of Greenhouse Gas Control, 63, 401-411.

Mulyana, A., \& Wirahadikusumah, R. D. (2017). Analisis Konsumsi Energi dan Emisi Gas Rumah Kaca pada Tahap Konstruksi Studi Kasus : Konstruksi Jalan Cisumdawu. Jurnal Teoritis Dan Terapan Bidang Rekayasa Sipil, 24(3), $269-280$.

Orecchini, F., Santiangeli, A., Zuccari, F., Ortenzi, F., Genovese, A., Spazzafumo, G., \& Nardone, L. (2018). Energy Consumption of a Last Generation Full Hybrid Vehicle Compared with a Conventional Vehicle in Real Drive Conditions. Energy Procedia, 148, 289-296.

O’Ryan, R., Nasirov, S., \& Álvarez-Espinosa, A. (2020). Renewable energy expansion in the Chilean power market: A dynamic general equilibrium modeling approach to determine CO2 emission baselines. Journal of Cleaner Production, $247,119645$.

Park, J. S., \& Seo, Y. J. (2016). The Impact of Seaports on the Regional Economies in South Korea: Panel Evidence from the Augmented Solow Model. Transportation Research Part E: Logistics and Transportation Review, 85, 107-119.

Reflis, R., Nurung, M., \& Pratiwi, J. D. (2011). Motivasi Petani Dalam Mempertahankan Sistem Tradisional Pada Usahatani Padi Sawah Di Desa Parbaju Julu Kabupaten Tapanuli Utara Propinsi Sumatera Utara. Jurnal AGRISEP: Kajian Masalah Sosial Ekonomi Pertanian dan Agribisnis, 10(1), 51-62.

Shang, X., Li, Z., Zheng, J., \& Wu, Q. H. (2019). Equivalent Modeling of Active Distribution Network Considering the Spatial Uncertainty of Renewable Energy Resources. International Journal of Electrical Power and Energy Systems, 112, 83-91.

Suhardi, R. P., \& Purwanto, A. (2015). Analisis Faktor-Faktor yang Mempengaruhi Pengungkapan Emisi Karbon di Indonesia (Studi Pada Perusahaan Yang Terdaftar di Bursa Efek Indonesia Periode 2010 - 2013). Diponegoro Journal of Accounting, 4(2), 1-13.

Tamura, S., Iwamoto, S., \& Tanaka, T. (2018). The impact of Spatial Population Distribution Patterns on $\mathrm{CO}_{2}$ Emissions and Infrastructure Costs in a Small Japanese Town. Sustainable Cities and Society, 40, 513-523.

Viviescas, C., Lima, L., Diuana, F. A., Vasquez, E., Ludovique, C., Silva, G. N., .. \& Paredes, J. R. (2019). Contribution of Variable Renewable Energy to increase energy security in Latin America: Complementarity and climate change impacts on wind and solar resources. Renewable and sustainable energy reviews, 113, 109232.

Wang, S., Zhou, C., Li, G., \& Feng, K. (2016). $\mathrm{CO}_{2}$, Economic Growth, and Energy Consumption in China's Provinces: Investigating the Spatiotemporal and Econometric Characteristics of China's $\mathrm{CO}_{2}$ Emissions. Ecological Indicators, 69, $184-195$.

Wang, T., Wen, Y., \& Lin, B. (2019). Energy Consumption and the Influencing Factors in China: A Nonlinear Perspective. Journal of Cleaner Production, 249, 119375.

Yeom, J. M., Deo, R. C., Adamwoski, J. F., Chae, T., Kim, D. S., Han, K. S., \& Kim, D. Y. (2020). Exploring solar and wind energy resources in North Korea with COMS MI geostationary satellite data coupled with numerical weather prediction reanalysis variables. Renewable and sustainable energy reviews, 119, 109570.

Zhang, D., Zhan, Q., Chen, Y., \& Li, S. (2016). Joint Optimization of Logistics Infrastructure Investments and Subsidies in a Regional Logistics Network with $\mathrm{CO}_{2}$ Emission Reduction Targets. Transport and Environment, 60, 174-190. 
Zhang, J., Fan, Z., Chen, Y., Gao, J., \& Liu, W. (2020). Decomposition and Decoupling Analysis of Carbon Dioxide Emissions from Economic Growth in the Context of China and the ASEAN Countries. Science of the Total Environment, 714, 136649. 